\title{
Nitrogen, phosphorus and silicon in riparian ecosystems along the Berg River (South Africa): The effect of increasing human land use
}

\author{
Eric Struyf ${ }^{1 *}$, Kris D Bal ${ }^{1,4}$, Hans Backx ${ }^{1}$, Dirk Vrebos ${ }^{1}$, Annelies Casteleyn ${ }^{1}$, Eric De Deckere ${ }^{1}$, \\ Jonas Schoelynck ${ }^{1}$, Luc Brendonck ${ }^{2}$, Lincoln M Raitt ${ }^{3}$ and Patrick Meire ${ }^{1}$ \\ ${ }^{1}$ Ecosystem Management Research Group, Department of Biology, University of Antwerp, Belgium \\ ${ }^{2}$ Laboratory of Aquatic Ecology and Evolutionary Biology, Katholieke Universiteit Leuven, Charles Deberiotstraat 32, 3000 Leuven, Belgium \\ ${ }^{3}$ Department of Biodiversity and Conservation Biology, University of the Western Cape, Cape Town, South Africa \\ ${ }^{4}$ Department of Biodiversity, University of Limpopo, Mankweng, South Africa
}

\begin{abstract}
The Berg River is one of the main rivers in the Cape Region; it is essential for the local economy and ecology, as it supplies water to agriculture and industries, provides drinking water for the greater Cape Town region, and supports rich aquatic ecosystems. The Berg River is impacted by both diffuse pollution from agricultural run-off and point-source pollution from urban and industrial wastewater. Construction of a dam on the headwaters of the Berg River in 2007 has changed the hydrology of the upper catchment. Pelagic nutrient dynamics in the Berg River are well documented. The opposite is however true for riparian nutrient dynamics. We studied changes in riparian nutrient storage over a gradient in elevation (a proxy for flooding frequency and drought) and human influence (the Berg River dam and lateral nutrient and pollutant input). Our results show that nutrient concentrations in the riparian sediments reflect nutrient concentrations in the river. N concentrations in the sediment increased up to $1000 \%$, while P concentrations rose up to $200 \%$ with increasing human influence. For biogenic $\mathrm{Si}$, we found generally low concentrations throughout the whole gradient sampled (all $<0.5 \mathrm{mg} \mathrm{BSi}$ $\mathrm{g}^{-1}$ sediment). Sediments closer to the river appear to have more efficient recycling and export of nutrients into the river. Overall, we conclude that the observed patterns indicate the necessity of incorporating nutrient status and management of riparian habitats in the Berg River monitoring strategy.
\end{abstract}

Keywords: Berg River, dam, nutrient dynamics, silica, nitrogen, phosphorus, vegetation, sediment

\section{Introduction}

The Cape Region (South Africa) is a biodiversity hotspot on the Southern African continent (Goldblatt and Manning, 2002). Due to human development, such as increasing agricultural activities and increasing urbanisation, ecosystems in the area have to cope with steadily increasing anthropogenic pressures, such as higher nutrient inputs, unsustainable water management practices, and, as a consequence, reductions in biodiversity (Rouget et al., 2003). Riverine water quality integrates these anthropogenic influences on the catchment scale. One of the main rivers in the Cape Region is the Berg River. It is essential for the local economy and ecology, as it supplies water to agriculture and industries, provides drinking water for the greater Cape Town region, and supports rich aquatic ecosystems (De Villiers, 2007).

The Berg River is nowadays impacted by both diffuse pollution from agricultural run-off and point-source pollution from urban and industrial wastewater. The construction of a dam on the headwaters of the Berg River in 2007 and other impoundments have changed the hydrology of the upper catchment. This combination of pollutant input and hydrological effects may impact on the ecological functioning of the entire river. In regulated rivers, a combination of short unpredictable

\footnotetext{
* To whom all correspondence should be addressed.

푱 +32 2652304; e-mail: eric.struyf@ua.ac.be

Received 5 September 2011; accepted in revised form 6 July 2012.
}

flood pulses and relatively long stable periods results in a cascade of effects on the aquatic organisms (Stanford et al., 1996; Ward et al., 2001).

Constructing reservoirs also strongly modifies biogeochemical cycles: carbon, nutrient and sediment loadings delivered to the coastal environment are strongly impacted due to increased residence times and increased stratification (Friedl and Wuest, 2002). For silica, in particular, it is well known that construction of dams has resulted in a decline in silica loads reaching estuaries and coastal environments (Humborg et al., 1997). The silica flux from the continents impacts on two of the major global carbon sinks (Street-Perrott and Barker, 2008), due to the link between weathering of minerals and atmospheric $\mathrm{CO}_{2}$ concentrations and the import of $\mathrm{Si}$ into coastal zones from the terrestrial environment sustaining diatom growth. Diatoms play a key role in the oceanic C sink (Ragueneau et al., 2006). In addition, Si plays an essential role in the occurrence of eutrophication problems in the coastal zone. The ratio at which $\mathrm{Si}, \mathrm{N}$ and $\mathrm{P}$ are delivered to the coastal zone from the continent is a determining factor for the occurrence of nuisance algal blooms (Cloern, 2001).

In contrast to most other African river systems, pelagic nutrient dynamics in the Berg River are well documented (De Villiers, 2007). This is, however, not the case for riparian nutrient dynamics, which remain poorly studied in African river systems (Jacobs et al., 2007). Riparian areas are wellestablished buffers in the $\mathrm{N}$ and $\mathrm{P}$ cycle. They affect the output of these nutrients to rivers through permanent or temporary uptake in vegetation, detritus and soils, and through 

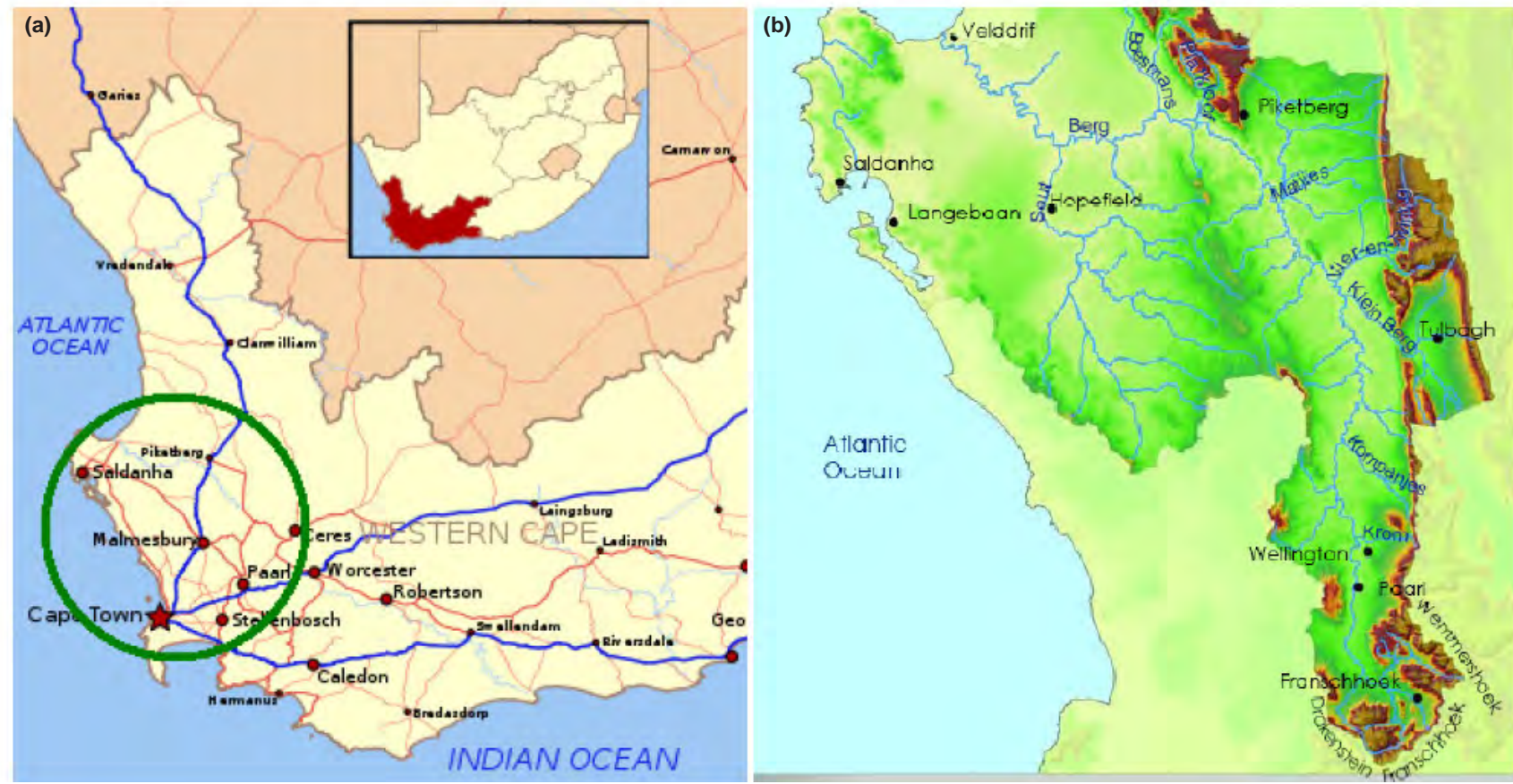

Figure 1

(a) Map showing location of the Berg River catchment in the Western Cape Province, South Africa, (b) Berg River catchment (Source: Department of Water Affairs, Republic of South-Africa)

transformation processes, e.g. removal by denitrification (e.g. Olde-Venterink et al., 2006). Riparian wetlands are often (re) established as a countermeasure against excessive $\mathrm{N}$ and $\mathrm{P}$ export from agricultural catchments. Recently, they have also been indicated as important filters for Si (Struyf and Conley, 2009; Struyf et al., 2011). Despite the importance of the riparian zone in riverine nutrient and sediment budgets, there is currently little or no documented information on nutrient dynamics in the Berg River floodplain.

The Berg River system provides a good opportunity to study hydrological impacts of elevation (flooding frequency and drought) and human disturbance effects on riparian biogeochemistry, in a system that has recently been heavily impacted (De Villiers, 2007), and which displays gradients of impact ranging from near-pristine to strongly humaninfluenced over relatively short distances. We studied changes in riparian nutrient dynamics over a gradient in elevation (a proxy for flooding frequency and drought) and human influence (the Berg River dam and lateral nutrient and pollutant input). This provides a dataset complementing existing data on pelagic nutrient dynamics in the Berg River. In contrast to most other studies on riparian nutrient dynamics, we included $\mathrm{Si}$ in our study. Si is an often understudied nutrient in riparian nutrient dynamics (Struyf and Conley, 2009; Struyf et al., 2009), yet riparian areas can play a crucial role in Si biogeochemistry. Our study aimed to identify Si, N and P stocks in riparian wetlands, as well as the effects of increasing human land use on these.

\section{Materials and methods}

\section{Study area}

The study area is located in the Upper Berg River, near the town

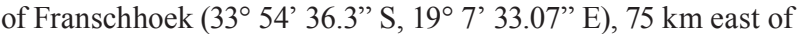

Cape town. The total catchment area for the Berg River is $7715 \mathrm{~km}^{2}$, including many of the famous vineyards of South Africa. 65\% of the catchment is used for agricultural purposes, mainly vineyards and fruit orchards. The Berg River has a length of $294 \mathrm{~km}$ and originates in the Hottentots-Holland Mountains at a height of $1500 \mathrm{~m}$ amsl. At the mouth it reaches the Atlantic Ocean forming an estuary of $61 \mathrm{~km}^{2}$ which is protected as an important bird area (Fig. 1).

Regional climate conditions are Mediterranean with an average rainfall in winter of 500 to $1000 \mathrm{~mm}$. The natural vegetation in this area is highly diverse with the most common plant families including Ericaceae, Proteaceae, Restionaceae and Poaceae. 30\% of the catchment still consists of this natural vegetation composition. The vegetation type is fynbos and is associated with low aquatic $\mathrm{pH}$ values $(<5.5)$, alkalinity $(<0.2 \mathrm{mM})$, ionic strength $(<1 \mathrm{mM})$ and a generally brownish water colour due to relatively high dissolved organic matter concentrations (DOC $<2.1 \mathrm{mg} \cdot \ell^{-1}$ ) (Soderberg, 2003).

The Berg River Dam was inaugurated on 5 March 2009. The ecological Reserve for water quantity of the upper Berg River catchment was set at $31.1 \%$ of the mean annual runoff. To realize these needs, the outlet works of the dam have been designed to release both low flows and high flows with provision for a peak release of up to $200 \mathrm{~m}^{3} \cdot \mathrm{s}^{-1}$. This makes it the first dam in South-Africa in which provision is made for flood releases for environmental purposes. A continuous low flow in the range from 0.3 to $12 \mathrm{~m}^{3} / \mathrm{s}$ is released and adjusted in magnitude according to the ecological demand and depending on the inflow into the Berg River Lake. In addition, flood events with different magnitudes are produced each year. These releases are performed simultaneously with natural flood events and have the same magnitude as the incoming flows. During periods of drought, the magnitude of the Reserve releases will be reduced in order to maintain a sufficient supply of drinking water. 


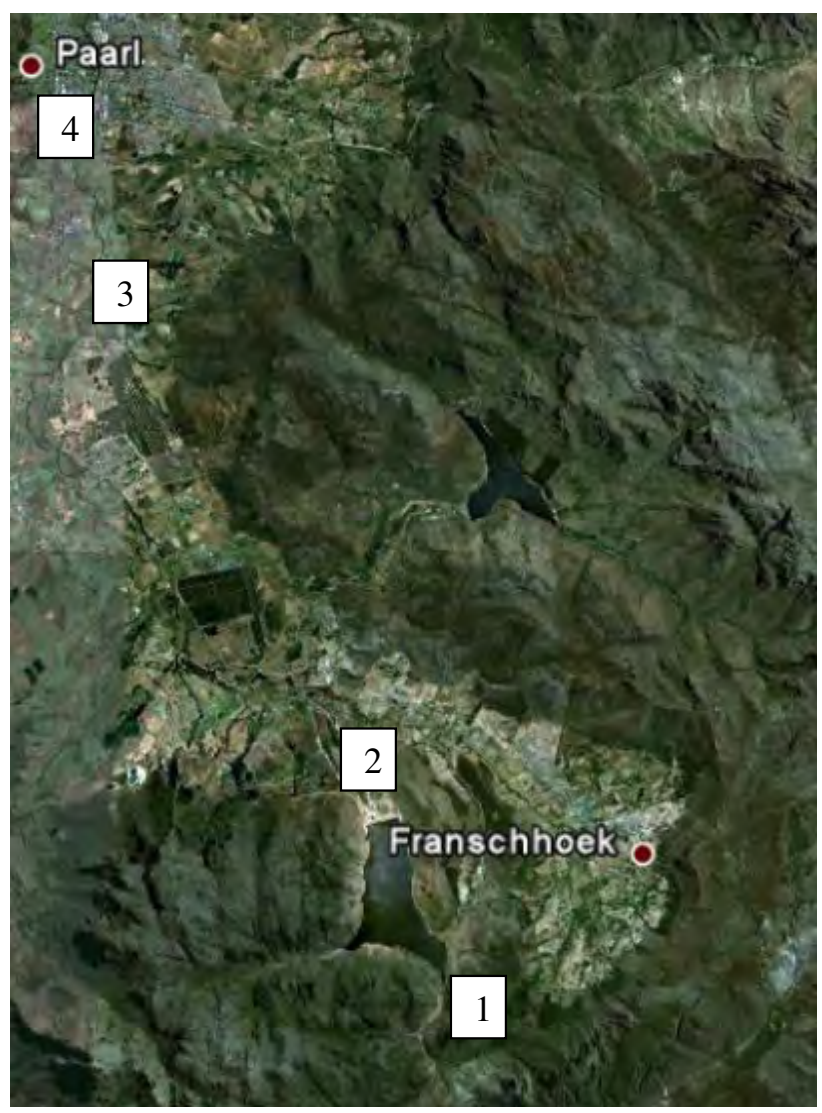

Figure 2

(Courtesy of Google Maps): Position of the 4 sampling locations along the Berg River. 1 (upstream Berg River Dam) and 2 (downstream Berg River Dam) are relatively undisturbed (except for the dam), 3 and 4 are subject to human diffuse and

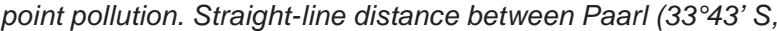
$18^{\circ} 57^{\prime} \mathrm{E}$ ) and Franschhoek ( $33^{\circ} 55^{\prime} \mathrm{S}, 1^{\circ} 8^{\prime} \mathrm{E}$ ) is $27 \mathrm{~km}$.

\section{Sampling}

\section{Locations}

Vegetation, sediment and pore water in riparian ecosystems were collected at 4 sampling locations within the upstream catchment area of the Berg River, representing a near-pristine to anthropogenic riverine gradient, in September 2009. The first 2 sampling locations were situated just above and below the Berg River dam, in an area close to the riverine source(s), where little pollutant and nutrient inputs are expected, and where vegetation in the catchment is mostly pristine (Fig. 2). The last 2 sampling locations were situated near the town of Paarl, approximately $35 \mathrm{~km}$ downstream from the first 2 sampling locations. Between the upper and the lower location the river receives water that has been impacted by vineyards and urban sewage (Fig. 2).

\section{Sampling setup}

At every location, we sampled inundation gradients for vegetation, sediment and pore water. Pore water and sediment samples were taken in gradients perpendicular to the river, representing a transition from regularly inundated areas (adjacent to the active channel, flooded as soon as water levels rise) to occasionally inundated areas (a few meters from the active channel, flooded only at high water levels). Sampling was performed at 3 plots along the perpendicular gradient (at Sampling

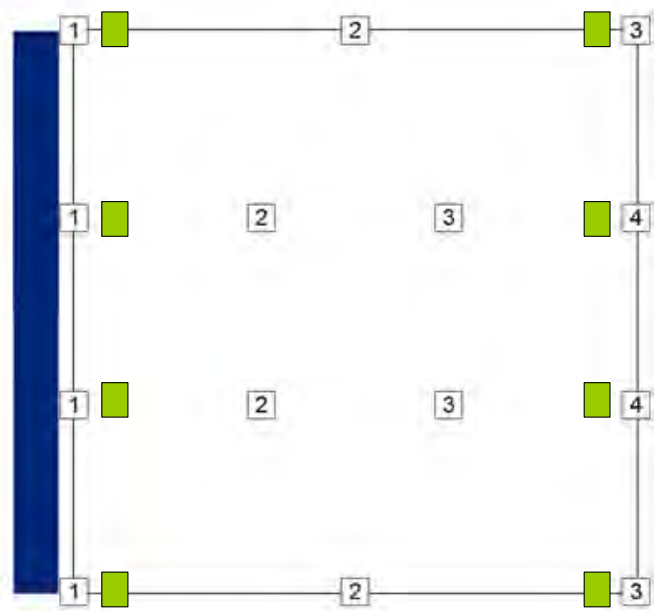

Figure 3

Outline of the natural neighbour plots. The most upstream station is at Sampling Location 1 (SL1), the most downstream station is at Sampling Location 4 (SL4). Numbered squares indicate inundation gradients perpendicular to the Berg River, where pore water and sediment were sampled. Inundation gradients consisted of 3 (most upstream and most downstream station) or 4 (intermediate stations) distances from the riverside. The number in the square indicates relative distance from the river. The Berg River Dam is between SL1 and SL2. SL1 and $S L 2$ are relatively undisturbed, SL3 and SL4 receive strong anthropogenic nutrient and pollutant input. The blue rectangle to the left represents the Berg River. Green rectangles represent plots where vegetation was sampled.

Locations 1 and 4) or at 4 plots along the perpendicular gradient (at Sampling Locations 2 and 3) (Fig. 3). Five parallel replicate perpendicular gradients were sampled to the river in each sampling location. The gravimetric soil water content in the samples confirmed the inundation gradient. Herbaceous and shrub vegetation was sampled at every sampling location at the outermost ends of the perpendicular gradients, in the most regularly inundated areas and the least frequently inundated areas, respectively, in 3 plots of $1 \mathrm{~m}^{2}$ (Fig. 3).

Sediment was sampled using Kopecky rings ( $5 \mathrm{~cm}$ height), with a fixed volume of $100 \mathrm{~cm}^{3}$ (Manufacturer: Eijkelkamp, certified soil sampling equipment, e.g. Javaux and Vanclooster, 2006). At each of the sampled plots, 2 Kopecky ring samples were pooled and analysed. Pore water was sampled in parallel to the Kopecky ring samples using polymerous rhizon samplers (Manufacturer: Eijkelkamp, diameter $2.5 \times 1.4 \mathrm{~mm}, 10$ cm length) (e.g. Struyf et al., 2009; Shotbolt, 2010). At every plot, the water content of 3 rhizon samplers was pooled. We were unable to sample pore water at the highest elevation at Sampling Location 2, which was also the driest site in terms of sediment water content. Plant samples were cut manually from a fixed area of $1 \mathrm{~m}^{2}$.

\section{Vegetation}

Table 1 provides an overview of the dominant vegetation occurring at all sampling stations. Sampling Location 1 had a high biodiversity with frequent occurrence of the following species: Briza maxima, Brabejum stellatifolium, Cotulata turbinata, Diospyros sp., Elegia capensis, Gladiolus sp., Helichrysum aureum, Hypochaeris radicata, Juncus sp., Metrosideros angustifolia, Moraea sp., Prionum serratum, Paspalum dilatatum, Pennisetum macrourum, Rumex sp., Scirpus fluitans 


\begin{tabular}{|l|c|c|c|c|}
\hline $\begin{array}{l}\text { Table 1 } \\
\text { Occurrence matrix of dominant species at all 4 sampling } \\
\text { locations. Sampling locations are indicated as 1, 2, 3 and } \\
\text { 4 respectively }\end{array}$ & $\mathbf{1}$ & $\mathbf{2}$ & $\mathbf{3}$ & $\mathbf{4}$ \\
\hline Species & $\mathbf{x}$ & & & \\
\hline Briza maxima L. & $\mathbf{x}$ & $\mathbf{x}$ & & \\
\hline Brabejum stellatifolium L. & & & $\mathbf{x}$ & $\mathbf{x}$ \\
\hline Commelina benghalensis L. & $\mathbf{x}$ & & & \\
\hline Cotula turbinate L. & $\mathbf{x}$ & & & \\
\hline Diospyros sp. & $\mathbf{x}$ & & & \\
\hline Elegia capensis (Burm.f.) Schelpe & & $\mathbf{x}$ & $\mathbf{x}$ & $\mathbf{x}$ \\
\hline Eleocharis sp. & $\mathbf{x}$ & & & \\
\hline Gladiolus sp. & $\mathbf{x}$ & $\mathbf{x}$ & & \\
\hline Hypochaeris radicata L. & $\mathbf{x}$ & & & \\
\hline Helichrysum aureum (Houtt.) Merr. & $\mathbf{x}$ & $\mathbf{x}$ & $\mathbf{x}$ & $\mathbf{x}$ \\
\hline Juncus sp. & & & $\mathbf{x}$ & \\
\hline Nymphaea lotus L. & & & $\mathbf{x}$ & $\mathbf{x}$ \\
\hline Myriophyllum aquaticum L. & $\mathbf{x}$ & $\mathbf{x}$ & & \\
\hline Metrosideros angustifolia (L.) Sm. & $\mathbf{x}$ & & & \\
\hline Moraea sp. & $\mathbf{x}$ & $\mathbf{x}$ & & \\
\hline Prionium serratum (L.F.) Drège ex E.Mey. & x & $\mathbf{x}$ & $\mathbf{x}$ & $\mathbf{x}$ \\
\hline Paspalum dilatatum Poir. & $\mathbf{x}$ & & $\mathbf{x}$ & $\mathbf{x}$ \\
\hline Pennisetum macrourum Trin. & & & $\mathbf{x}$ & $\mathbf{x}$ \\
\hline Polygonum sp. & $\mathbf{x}$ & & & $\mathbf{x}$ \\
\hline Rumex sp. & $\mathbf{x}$ & & & \\
\hline Isolepis fluitans (L.) R.Br. var. fluitans & $\mathbf{x}$ & & & \\
\hline Ursinia paleacea (L.) Moench & & & \\
\hline
\end{tabular}

and Ursinia paleacea. U. paleacea and P. macrourum characterised the most frequently flooded zone. $H$. radicata and B. maxima were restricted to the occasionally flooded higher zones (for flooding separation, see explanation above).

Sampling Location 2 had the following dominant species: B. stellatifolium, Eleocharis sp., H. radicata, Juncus sp., $M$. angustifolia, $P$. serratum and $P$. dilatatum. The last species was only found in the sporadically flooded zone. All other species were found at both flooding frequencies.

Sampling Location 3 had the following dominant species: Commelina benghalensis, Eleocharis sp., Juncus sp., Myriophyllum aquaticum, Nymphaea lotus, P. dilatatum, $P$. macrourum and Polygonum sp. Commelina benghalensis, $M$. aquaticum and $P$. macrourum were only found in the frequently flooded zone. The occasionally flooded zone was characterised by P. dilatatum.

At Sampling Location 4 the following species were dominant at both flooding frequencies: $C$. benghalensis, Eleocharis sp., Juncus sp., M. aquaticum, $P$ dilatatum, P. macrourum, Polygonum sp. and Rumex sp.

There was a general tendency of a decrease in the number of dominant species from the most upstream location to the most downstream location.

\section{Analysis}

The plant samples were thoroughly cleaned with demineralised water to remove sediments, epiphytic algae and macroinvertebrates. They were then dried at $70^{\circ} \mathrm{C}$ for $48 \mathrm{~h}$ until a constant mass was reached. Dry biomass was then determined, after which the dried material was homogenised and ground to $500 \mu \mathrm{m}$. Biogenic silica (BSi) was extracted from $25 \mathrm{mg}$ of this dried plant material by incubation in a $0.1 \mathrm{~m} \mathrm{Na}_{2} \mathrm{CO}_{3}$ mixture at $80^{\circ} \mathrm{C}$ for $4 \mathrm{~h}$ (Struyf et al., 2005). The extracted and dissolved
Si was spectrophotometrically analysed on IRIS ${ }^{\circledR}$ ICP (inductively coupled plasma spectrophotometer, Thermo $\left.{ }^{\circledR}\right)$. Nitrogen and phosphorus content were obtained by digesting $0.2 \mathrm{~g}$ dried plant material $\left(48 \mathrm{~h}\right.$ at $70{ }^{\circ} \mathrm{C}$ ) using a $\mathrm{H}_{2} \mathrm{SO}_{4}-\mathrm{H}_{2} \mathrm{O}_{2}$ digestion (Walinga et al., 1989) followed by a colorimetric analysis of the digested material on a 'Segmented Flow Analyzer Skalar' (e.g. Van Damme et al., 2009).

Pore water DSi concentrations were measured on an ICP (inductively coupled plasma spectrophotometer). Pore water $\mathrm{PO}_{4}^{3-}, \mathrm{NH}_{4}^{+}$and $\mathrm{NO}_{\mathrm{x}}^{-}$concentrations were analysed colorimetrically on a 'Segmented Flow Analyzer Skalar' (e.g. Van Damme et al., 2009).

Sediment samples were dried at $70^{\circ} \mathrm{C}$ for $48 \mathrm{~h}$. BSi in the sediment was determined by alkaline extraction of $30 \mathrm{mg}$ of oven-dried sediment in $1 \% \mathrm{Na}_{2} \mathrm{CO}_{3}$ solution over a $5 \mathrm{~h}$ period with sub-samples taken at 3, 4 and 5 h, as adapted by Conley and Schelske (2002). Nitrogen and phosphorus content of sediment samples were analysed according to the method as described above for plants (Walinga et al., 1989).

\section{Statistics}

Plots for nutrient concentrations in sediment and pore water were constructed by calculating natural neighbour interpolations between the neighbouring sample plots (Sibson, 1981). In practice, for plotting purposes, all 4 sampling locations were set at an equal distance and natural neighbour interpolations were calculated using the natural neighbour tool from Spatial Analyst in ArcGIS 9.3 (ESRI Inc., 2009). The natural neighbour tool is a good tool to infer trends in a spatial dataset: it will never produce values outside of the sampled dataset. These plots provide a strong visual interpretation of the studied gradients and capture local variability, as every point for sediments is an average concentration for 10 Kopecky ring samples (5 perpendicular replicate gradients in every sampling location, 2 Kopecky rings per distance from river in every replicate gradient). Pore water concentration at every sampling point within these kriged plots was the average for 3-15 rhizons (5 perpendicular replicate gradients at every sampling location, 3 rhizons per distance from river in every replicate gradient), depending on the success rate of rhizon samplers at the particular location.

Vegetation nutrient content and biomass across the sampled area was analysed using 2-way ANOVA with location and flooding frequency as independent factors. For vegetation, only the lowest and highest flooding frequency was sampled. For vegetation, no individual species were analysed. All analyses were performed on bulked vegetation samples, for all biomass in plots of $1 \mathrm{~m}^{2}$.

\section{Results}

\section{Vegetation}

Total vegetation biomass in the sampled plots differed significantly between locations and along the inundation gradient (Fig. 4 and Table 2). The frequently flooded zone of Location 2 had a significantly higher biomass than the other locations and zones, except for the frequently flooded zone of Location 1. Highest BSi concentrations were found in the frequently flooded zones of Locations 1 and 2, the lowest at Locations 3 and 4 . For $\mathrm{N}$ and $\mathrm{P}$ content 2 significant groups could be identified. $\mathrm{N}$ and $\mathrm{P}$ concentrations showed a significant downstream increase. Highest concentrations were found at Locations 3 and 4, lowest concentrations at Locations 1 and 2. Within these 

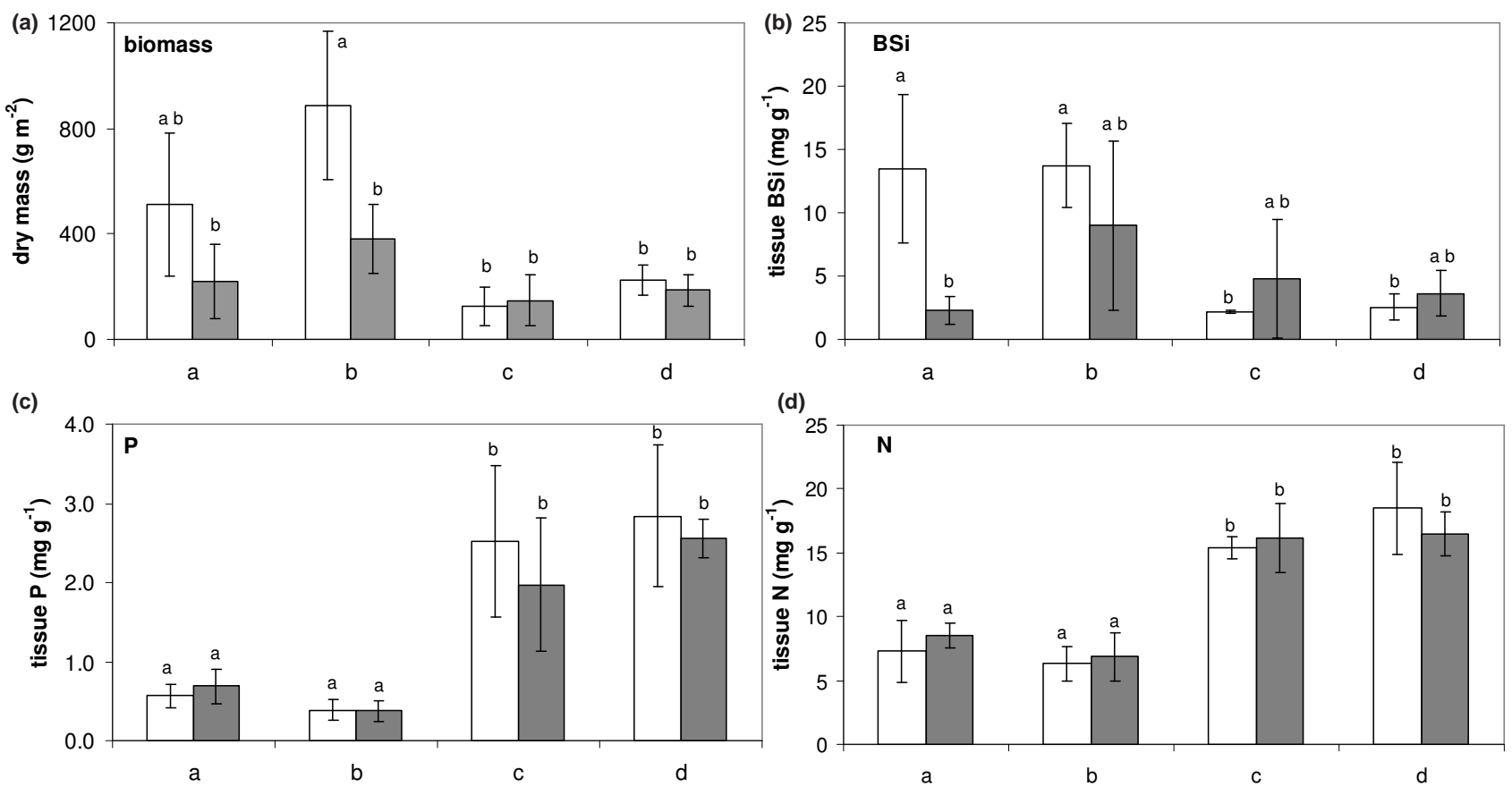

Figure 4

(a) Dry biomass per square meter, (b) biogenic silica, (c) phosphorus and (d) tissue nitrogen concentrations, at the different sampling locations ( $a=$ Sampling Location $1, b=$ Sampling Location 2 , $c=$ Sampling Location 3, $d=$ Sampling Location 4) and plots within the locations (white = frequently flooded, grey $=$ occasionally flooded). Error bars represent standard deviations. Above the bars the results of a 2-way ANOVA and Scheffé post-hoc test are inserted; 'a' and 'b' are significantly different from each other; 'ab' does not differ significantly from either ' $a$ ' or ' $b$ ' (see Table 2).

\begin{tabular}{|l|c|c|c|c|}
\hline \multicolumn{5}{|c|}{$\begin{array}{c}\text { Table 2 } \\
\text { An overview of the statistical analysis (2-way ANOVA, with flooding frequency } \\
\text { and location as independent factors) of the biomass, N, P and Si content of the } \\
\text { vegetation at the plots at the 4 sampling locations and 2 flooding frequencies. } \\
\text { Significant differences are indicated in bold. }\end{array}$} \\
\hline & BSi & N & P & Biomass \\
\hline Location & $F=9.72$ & $F=49.85$ & $F=35.24$ & $F=19.61$ \\
& $\boldsymbol{p}<\mathbf{0 . 0 0 1}$ & $\boldsymbol{p}<\mathbf{0 . 0 0 1}$ & $\boldsymbol{p}<\mathbf{0 . 0 0 1}$ & $\boldsymbol{p}<\mathbf{0 . 0 0 1}$ \\
\hline Flood frequency & $F=5.90$ & $F=0.02$ & $F=0.79$ & $F=15.84$ \\
& $\boldsymbol{p}<\mathbf{0 . 0 3}$ & $p=0.88$ & $p=0.38$ & $\boldsymbol{p}<\mathbf{0 . 0 0 1}$ \\
\hline Interaction & $F=6.11$ & $F=0.92$ & $F=0.48$ & $F=5.86$ \\
& $\boldsymbol{p}<\mathbf{0 . 0 1}$ & $p=0.45$ & $p=0.70$ & $\boldsymbol{p}<\mathbf{0 . 0 1}$ \\
\hline
\end{tabular}

sites no significant differences in $\mathrm{N}$ and $\mathrm{P}$ tissue concentration were detected between frequently and occasionally flooded zones (results of all tests are indicated in Table 2 and Fig. 4).

\section{Sediment}

All pore water and sediment data are summarised in Table 3. Water content in the sediment was always highest nearest the river, at all 4 sampling stations. This confirmed our assumption that our gradients perpendicular to the river were indicative for flooding frequency and drought (Fig. 5). Location 3 had generally higher water content along the perpendicular gradient than the other locations, which all had similar water content.

Sediment P content was always higher, over the whole inundation gradient, above the dam $\left(0.1 \mathrm{mg} \cdot \mathrm{g}^{-1}\right)$ in comparison to the locations directly below the Berg River dam (0.04 $\left.\mathrm{mg} \cdot \mathrm{g}^{-1}\right)$. It increased again slightly further downstream, especially at the highest sampling plots, and was highest at the most downstream and most urban sampling location $\left(0.14 \mathrm{mg} \cdot \mathrm{g}^{-1}\right)$ (Fig. 6).

Sediment $\mathrm{N}$ content showed a gradual increase over the whole longitudinal sampling gradient, with lowest $\mathrm{N}$ concentrations found at Sampling Location 1 (down to $0.06 \mathrm{mg} \cdot \mathrm{g}^{-1}$ ), and with a gradual increase in $\mathrm{N}$ content further downstream (up to $0.62 \mathrm{mg} \cdot \mathrm{g}^{-1}$ ). There was no apparent tendency for higher or lower $\mathrm{N}$ concentrations in relation to flooding frequency (Fig. 6).

BSi content in the sediment was highest at Sampling Location 2, just downstream of the dam $\left(0.43 \mathrm{mg} \cdot \mathrm{g}^{-1}\right)$. There was little variation in BSi content between the other sites: at Sampling Locations 1 and 3, it was highest in the upper section of the flooding gradient $\left(\sim 0.25 \mathrm{mg} \cdot \mathrm{g}^{-1}\right)$, at Sampling Location 4 it was highest near the river. Lowest observed BSi concentrations was $0.06 \mathrm{mg}^{-1} \mathrm{~g}^{-1}$ (Fig. 7).

These patterns resulted in gradually decreasing $\mathrm{Si} / \mathrm{N}$ ratios in the sediment downstream, and equivalent $\mathrm{Si} / \mathrm{P}$ ratios over the whole longitudinal gradient, except at Sampling Location 


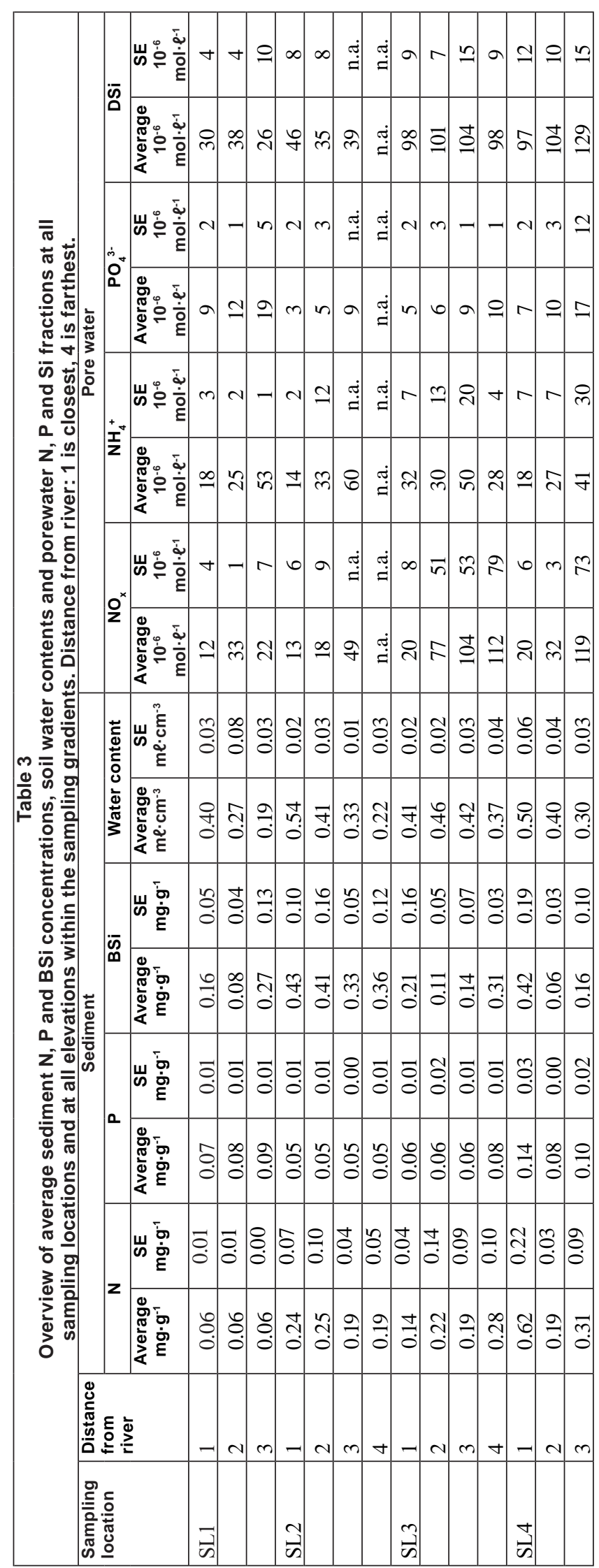

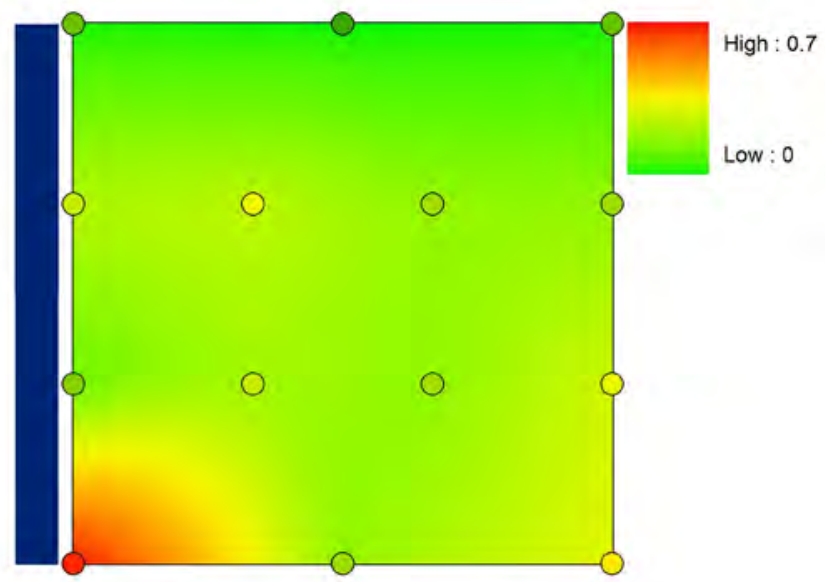

Figure 6

Top panel: Sediment $P$ content $\left(m g \cdot g^{-1}\right)$. Lower panel: Sediment $N$ content $\left(m g \cdot g^{-1}\right)$. For details, see legend of Fig. 3 and Fig. 5. 


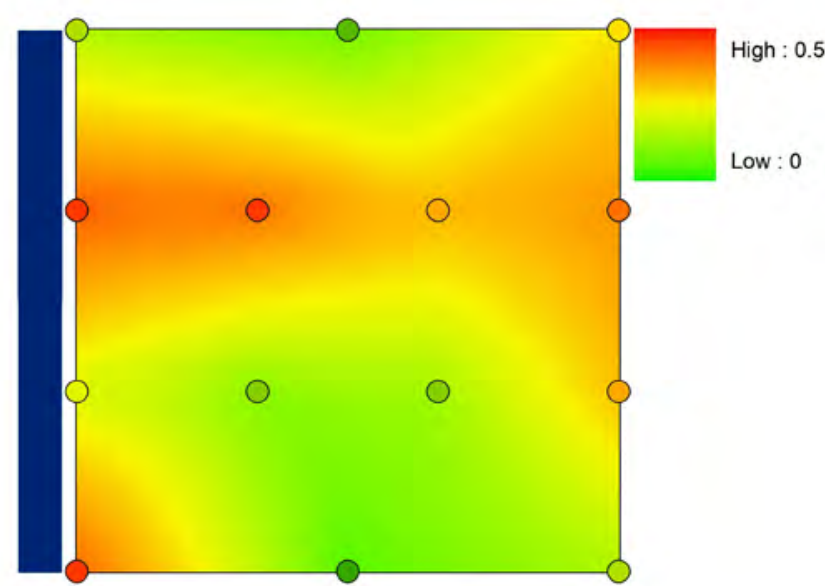

Figure 7

Sediment BSi content $\left(m g \cdot g^{-1}\right)$.

For details, see legend of Fig. 3 and Fig. 5.

2, which had higher Si/P ratios. N/P ratio was lowest at the most upstream site, and highest just below the dam. The other sites had intermediate N/P ratios with no clear pattern linked to inundation observed (Fig. 8).

\section{Pore water}

Pore water DSi concentrations were lowest at the 2 upstream sites, and were 4 times higher at the 2 downstream sites (Fig. 9). A similar pattern was observed for $\mathrm{NO}_{x}$ along the longitudinal gradient, although the lowest concentrations were generally observed at Sampling Station $1 . \mathrm{NO}_{\mathrm{x}}$ concentrations were always lowest at the sampling sites nearest to the river. A similar flooding frequency pattern was observed for $\mathrm{NH}_{4}^{+}$ concentrations, which were always higher at sampling spots farthest from the river. $\mathrm{NH}_{4}^{+}$concentrations were higher at the 2 most upstream stations. This resulted in a gradual increase in TDIN (total dissolved inorganic $\mathrm{N}, \mathrm{NH}_{4}^{+}+\mathrm{NO}_{\mathrm{x}}$ ) concentrations along the longitudinal river gradient for spots with lowest flooding frequency, and consequently low TDIN concentrations in pore water near the river (Fig. 10).

There was a general tendency for highest $\mathrm{PO}_{4}^{3-}$ concentrations at lowest flooding frequencies. No longitudinal riverine patterns in dissolved $\mathrm{P}$ were observed (Fig. 9).

\section{Discussion}

As riparian habitats are important $\mathrm{N}$ and $\mathrm{P}$ buffers along streams and retain important parts of lateral $\mathrm{N}$ and $\mathrm{P}$ inputs into rivers (e.g. Lee et al., 2000), the potential for significant increases in riparian nutrients is high with increasing human land use. Nevertheless this aspect has not been studied in the past for the Berg River. Nutrient input in riparian wetlands is dependent on hydrology: the source can either be lateral groundwater input or floodwater input from the river (Osborne and Kovacic, 1993; Brinson, 1993). We observed increases in sediment $\mathrm{N}$ and $\mathrm{P}$ concentrations from upstream near-pristine to downstream impacted locations. $\mathrm{N}$ concentrations in the sediment increased by up to $1000 \%$, while P concentrations rose by up to $200 \%$. The shift in $\mathrm{N}$ and $\mathrm{P}$ availability in sediments was clearly reflected in the plant $\mathrm{N}$ and $\mathrm{P}$ content, which also shifted strongly downstream and increased by about $200 \%$. At the same time, there was a clear shift in the number of dominant species, which was highest in the upstream locations, and
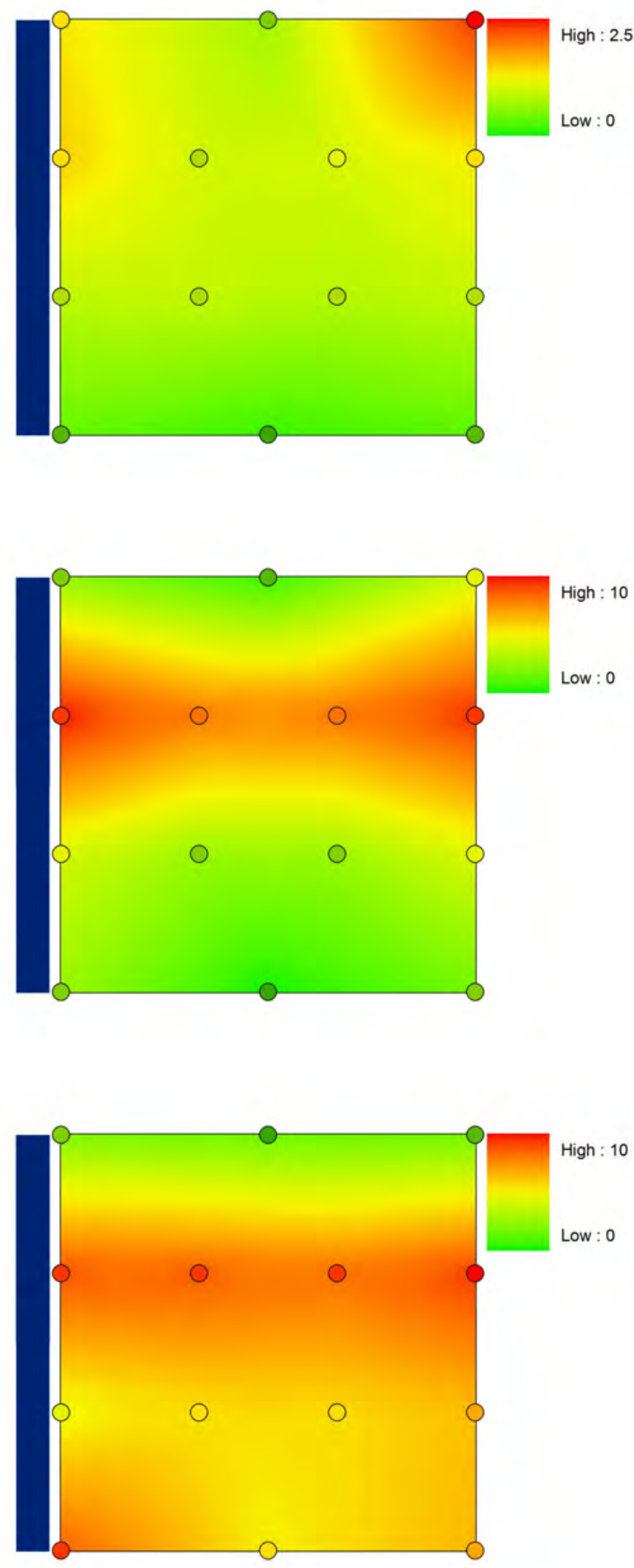

Figure 8

Molar sediment Si/N (top panel), Si/P (middle panel) and N/P (lower panel) ratios (mol/mol). For details, see legend of Fig. 3 and Fig. 5.

lowest in the downstream locations. This potentially reflects a decrease in biodiversity with increasing nutrient availability. Nutrient biogeochemistry in riparian soils is linked to productivity of the vegetation and could have long-lasting effects on 

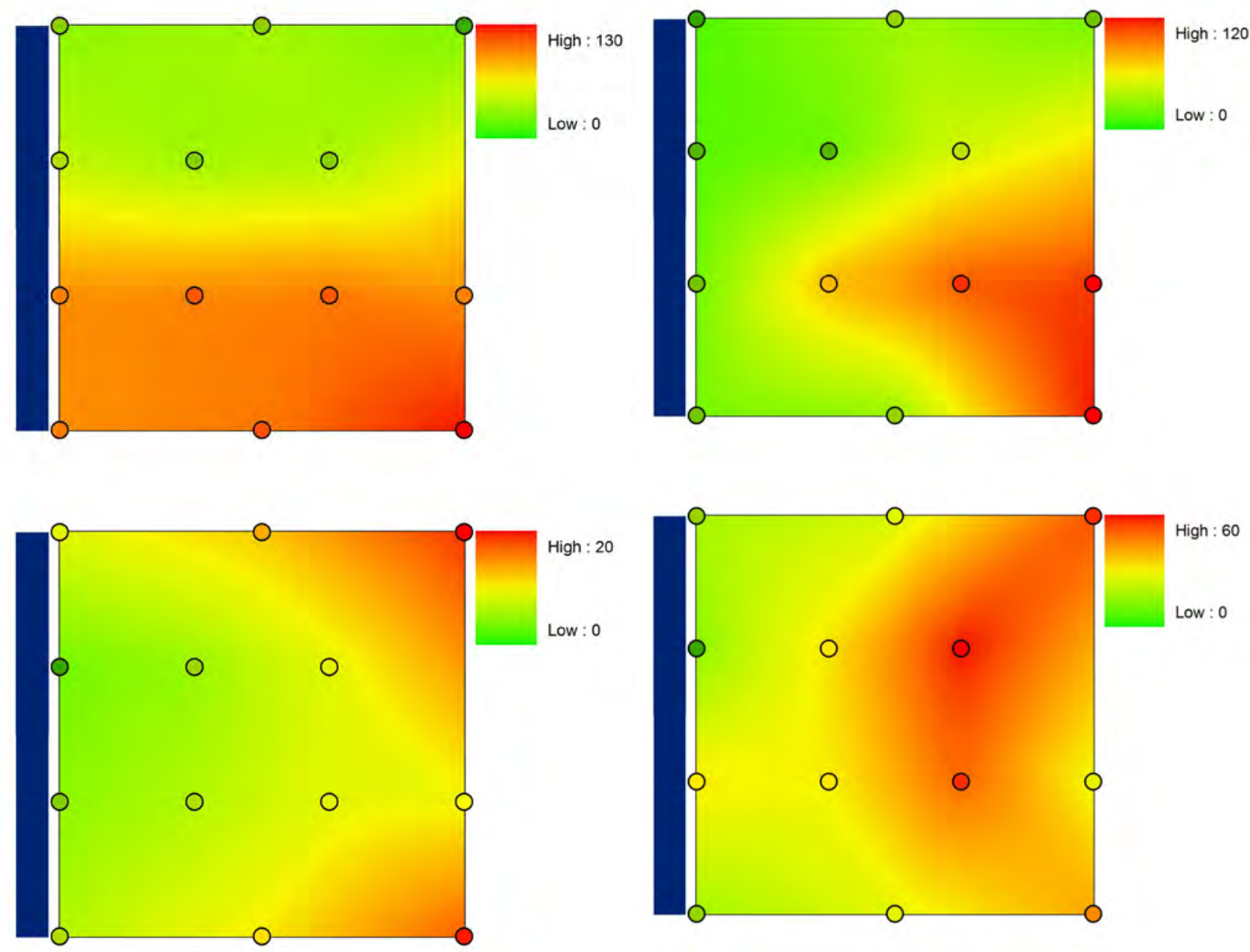

\section{Figure 9}

Pore water DSi (top panel) and $\mathrm{PO}_{4}{ }^{3-}$ (lower panel) concentrations $\left(\mu \mathrm{mol} \ell^{-1}\right)$. For details, see legend of Fig. 3 and Fig. 5.

biodiversity. Shifts in riparian nutrients are often correlated to shifts in biodiversity (Bedford et al., 1999; Wassen et al., 2003) and hence shifts in the ecological functioning of the riparian ecotone (Tabacchi et al., 1998). In contrast to the expected positive relationship with nutrient loading, biomass was generally lowest at the most downstream locations. This was most likely a by-product of the sampling season: the downstream locations were greatly subjected to human management (mowing) and characterised by opportunistic, annual species. As we sampled at the beginning of the growth season (September 2009), this resulted in generally low biomass at the downstream sampling locations. Additional sampling through different seasons could provide more insight.

In a semi-arid savannah riparian zone in South Africa, nitrogen storage is strongly associated to soil particle size (Bechtold and Naiman, 2006). However, we did not analyse soil particle size and cannot determine its role in $\mathrm{N}$ storage in our study. This certainly warrants further investigation. Nitrogen mineralisation and storage tend to increase along the length of rivers even without human interference (e.g. Evans et al., 2011), but this is unlikely to explain the strong increase we observed over the relatively short distance of $35 \mathrm{~km}$. The $\mathrm{N}$ to $\mathrm{P}$ ratio in the sediment increased downstream, reflecting the higher relative increase in $\mathrm{N}$. The results generally show that changes in riverine water quality, as indicated by De Villiers (2007), are

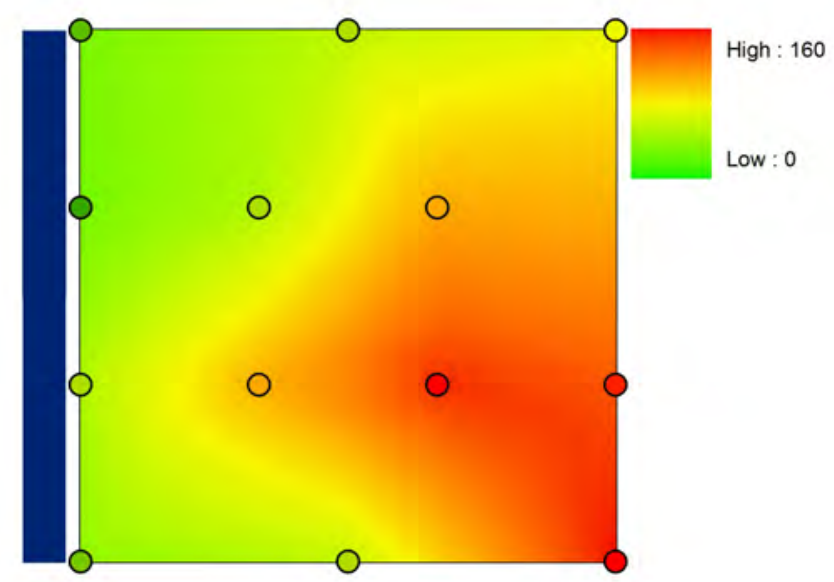

Figure 10

Pore water $\mathrm{NO}_{x}$ (top panel), $\mathrm{NH}_{4}^{+}$(middle panel) and TDIN (lower panel) concentrations $\left(\mu \mathrm{mol} \cdot \ell^{1}\right)$. For details, see legend of Fig. 3 and Fig. 5.

directly reflected in the riparian soils.

The Berg River has had to cope with increasing inputs of fertilisers, nutrients and pollutants from domestic, agricultural and industrial wastewater. As a result, the nutrient status of the river has deteriorated over the past decades, which De Villiers (2007) clearly showed in her review paper on nutrients in the 
Berg River. This has already resulted in declining fishery yields, as well as increasing dominance of water plant species associated with eutrophic or hypertrophic conditions (Paulse et al., 2007). The Berg River catchment is generally characterised by a nutrient-poor lithology (De Villiers, 2007). Low base input of nutrients to the river and the riverine floodplain is the pristine situation: vegetation in the catchment will retain the scarce available nutrients as efficiently as possible. This means there is a high potential for strong relative nutrient enrichment of the receiving aquatic systems when human-induced nutrient inputs increase. De Villiers (2007) indicated up to $1000 \%$ increases in dissolved $\mathrm{N}$ and $\mathrm{P}$ concentrations compared to pristine conditions in the Berg River water, while South African water quality guidelines stipulate that inorganic $\mathrm{N}$ and $\mathrm{P}$ concentrations should not change by more than $15 \%$ from unimpacted conditions at any time of the year. The increases in $\mathrm{N}$ and $\mathrm{P}$ content we observed between impacted and un-impacted sites likely reflect the effect of human-induced nutrient enrichment.

The increase in relative availability of $\mathrm{N}$ and $\mathrm{P}$ in the sediments and higher $\mathrm{N}$ and $\mathrm{P}$ concentrations in the vegetation was not reflected in an equally clear increase in dissolved $\mathrm{N}$ and $\mathrm{P}$ fractions in the pore water. There was however a general tendency for all dissolved $\mathrm{N}$ and $\mathrm{P}$ fractions to increase along the elevation gradient, with highest pore water concentrations observed at the least flooded locations. We hypothesize that this reflects the level of nutrient exchange with the river water. The most frequently flooded locations have the most frequent exchange of water with the river, as was reflected in the soil water content. Riverine concentrations of TDIN were measured twice at each location during the sampling campaign, and TDIN increased from 20 to $40 \mu \mathrm{mol} \cdot \ell^{-1}$ between the two most upstream and the two most downstream sites. This is about $2-4$ times lower than the concentrations observed in the pore water. Frequent refreshing of pore water will hence result in lower TDIN concentrations in the pore water. For dissolved P, riverine concentrations did not change along the river, and remained between 0.4 and $0.8 \mu \mathrm{mol} \cdot \ell^{-1}$, which is much lower than concentrations observed in the pore water $\left(5-20 \mu \mathrm{mol} \cdot \ell^{-1}\right)$. This again resulted in lower $\mathrm{P}$ concentrations in pore water close to the river. For $\mathrm{P}$, this mechanism may be enhanced by the increased release of $\mathrm{P}$ from $\mathrm{Fe}$-oxides under reductive conditions (higher water content) in the frequently flooded, wetter locations close to the river (e.g. Moore and Reddy, 1994; Surridge et al., 2007). The $\mathrm{N}$ and $\mathrm{P}$ stocks, which are now built-up in the riparian sediments, could become a challenge for future management of riverine water quality, as they could provide a source of nutrients for years to come.

For biogenic $\mathrm{Si}$, we found generally low concentrations throughout the whole sampled gradient (all $<0.5 \mathrm{mg} \mathrm{BSi} \mathrm{g}^{-1}$ sediment); these concentrations are also low in comparison to previous studies on BSi in wetland sediments. Earlier studies showed concentrations up to $100 \mathrm{mg} \cdot \mathrm{g}^{-1}$ in sub-arctic wetlands (Struyf et al., 2010), 4-14 mg.g-1 in tidal freshwater and mesohaline sediments (Norris and Hackney, 1999; Struyf et al., 2005) and 0.5 to $2.5 \mathrm{mg} \cdot \mathrm{g}-{ }^{1}$ in Everglades mangrove soils (Jensen et al., 1999). The slightly higher BSi concentrations at Sampling Location 2 could be linked to elevated BSi contents in vegetation. Vegetation is a potentially important control on sediment BSi concentrations (Struyf et al., 2009). The low $\mathrm{BSi}$ concentrations potentially reflect low input of BSi into the riparian zone from the river (reflecting low primary productivity of diatoms in the river) or the occurrence of mostly perennial plants which efficiently retain $\mathrm{BSi}$, as well as the generally nutrient-poor lithologies within the catchment. We can also assume that in the Berg River riparian areas are more important in the $\mathrm{N}$ and $\mathrm{P}$ cycle compared to the Si cycle, as they apparently retain only a small fraction of $\mathrm{Si}$ in a biogenic form.

The pore water DSi concentrations were also low (26-128 $\left.\mu \mathrm{mol} \cdot \ell^{-1}\right)$, compared to, e.g., $300-600 \mu \mathrm{mol} \cdot \ell^{-1}$ in freshwater tidal sediments (Struyf et al., 2005). These pore water concentrations are far below saturation concentrations for biogenic Si $\left(\sim 2000 \mu \mathrm{mol} \cdot \ell^{-1}\right)$. This probably indicates that plant BSi deposited in the sediments quickly dissolves after deposition. Studies which have included both BSi in wetland sediments and DSi in pore water seem to suggest a mechanism whereby low DSi in wetland soils is generally associated with low BSi in the soils (as all deposited BSi quickly dissolves) (Struyf et al., 2005; Struyf et al., 2009; this study). This actually implies that a certain threshold level of BSi deposition is needed to obtain substantially higher DSi concentrations, consequently slowing down relative BSi dissolution and stimulating further BSi deposition, which in turn favours high DSi concentrations.

\section{Conclusions}

Our study has provided a first analysis of nutrient stocks in riparian habitats along the upper reaches of the Berg River, after dam construction. We showed that nutrient concentrations in the riparian sediments reflect nutrient concentrations in the river. Sediments closer to the river furthermore had more efficient recycling and export of nutrients into the river. In 2007, De Villiers predicted that both hydrological changes and continued development will result in further increases in nutrient levels in the river. Our results seem to imply that this will result in further nutrient enrichment in the riparian zone.

The strongly shifting nutrient status of the riparian zone could affect all functions generally associated with these habitats. It may change the habitat function for vegetation, as it will favour fast-growing annual plants over typically perennial fynbos vegetation. This will in turn affect associated fauna. The natural filter function will also be affected: it is uncertain whether this will still hold at higher nutrient levels, and our results already show that riparian zones could actually become a source of nutrients to the river in the future. Changes in vegetation will further alter the flooding characteristics and thus erosion-sedimentation characteristics. Major habitat changes could be expected as a result. Finally, the loss of native vegetation could also inflict a reduced affinity of the local community for the habitat, which could result in further deterioration as a result of reduced management efforts.

Overall, we conclude that the observed patterns indicate the necessity of incorporating nutrient status and management of riparian habitats in the Berg River monitoring strategy. As deterioration in the Berg River has not reached levels observed in similar rivers in, e.g., Mediterranean areas, lessons learned from such an integrated monitoring could become an example for the management of more deteriorated systems.

\section{Acknowledgements}

Eric Struyf thanks FWO (Research Foundation Flanders) for personal postdoctoral research funding and for Grant G.0443.05 'Impact of hydrology on diversity of aquatic organisms in temporary wetlands in the Cape Region (South Africa)'. We also acknowledge the Belgian Science Policy (BELSPO, $\mathrm{SD} / \mathrm{NS} / 05 \mathrm{a}$ ) for funding the project 'LUSi: land use changes and silica fluxes in the Scheldt river basin' and FWO for funding project 'Tracking the biological control on Si mobilisation 
in upland ecosystems' (Project No. G014609N). We are also grateful to the VLIR IUC project 'Water for ecological sustainability' with the University of the Western Cape that facilitated our research and collaboration with local partners. Jonas Schoelynck thanks IWT (Institute for the Promotion of Innovation by Science and Technology in Flanders) for personal research funding.

\section{References}

BECHTOLD J and NAIMAN RJ (2006) Soil texture and nitrogen mineralization potential across a riparian toposequence in a semi-arid savanna. Soil Biol. Biochem. 38 1325-1333.

BEDFORD BL, WALBRIDGE MR and ALDOUS A (1999) Patterns in nutrient availability and plant diversity of temperate North American wetlands. Ecology 80 2151-2169.

BRINSON MM (1993) Changes in the functioning of wetland along environmental gradients. Wetlands 13 65-74.

CLOERN JE (2001) Our evolving conceptual model of the coastal eutrophication problem. Mar. Ecol. Prog. Ser. 210 223-253.

CONLEY DJ and SCHELSKE CL (2001) Biogenic silica. In: Smol JP, Birks HJB, Last WM (ed.) Tracking Environmental Change Using Lake Sediments: Biological Methods and Indicators. Kluwer Academic Press, Dordrecht. 281-293

DE VILLIERS S (2007) The deteriorating nutrient status of the Berg River, South Africa. Water SA 33 659-664.

EVANS DM, SCHOENHOLTZ SH, WIGINGTON PJ and GRIFFITH SM (2011) Nitrogen mineralization in riparian soils along a river continuum within a multi-land-use basin. Soil Sci. Soc. Am. J. 75 719-728.

FRIEDL G and WUEST A (2002) Disrupting biogeochemical cycles Consequences of damming. Aquat. Sci. 64 55-65.

HUMBORG C, ITTEKOT V, COCIASU A and VON BODUNGEN B (1997) Effect of Danube River dam on Black Sea biogeochemistry and ecosystem structure. Nature 386 385-388.

MYERS N, MITTERMEIER RA, MITTERMEIER CG, DA FONSECA GAB and KENT J (2000) Biodiversity hotspots for conservation priorities. Nature 403 853-858.

GOLDBLATT P and MANNING J (2002) Plant diversity of the Cape Region of South Africa. Ann. Missouri Bot. Gard. 89 281-302.

JACOBS S, BECHTOLD J, BIGGS H, GRIMM N, LORENTZ S, McCLAIN M, NAIMAN R, PERAKIS S, PINAY G and SCHOLES M (2007) Nutrient vectors and riparian processing: A Review with special reference to African semiarid savanna ecosystems. Ecosystems 10 1231-1249.

JAVAUX M and VANCLOOSTER M (2006) Scale-dependency of the hydraulic properties of a variably saturated heterogeneous sandy subsoil. J. Hydrol. 327 376-88.

JENSEN JE, COOPER SR and RICHARDSON CJ (1999) Calibration of modern pollen along a nutrient gradient in Everglades Water Conservation Area-2A. Wetlands 19 675-688.

LEE KH, ISENHART TM, SCHULTZ RC and MICKELSON SK (2000) Multispecies riparian buffers trap sediment and nutrients during rainfall simulations. J. Environ. Qual. 29 1200-1205.

MOORE PA and REDDY KR (1994) Role of EH and pH on phosphorus geochemistry in sediments of Lake Okeechobee, Florida. J. Environ. Qual. 23 955-964.

NORRIS AR and HACKNEY CT (1999) Silica content of a mesohaline tidal marsh in North Carolina. Est. Coast. Shelf Sci. 49 597-605.

OLDE VENTERINK H, VERMAAT JE, PRONK M, WIEGMAN F, VAN DER LEE GEM, VAN DEN HOORN MW, HIGLER L and VERHOEVEN JTA (2006) Importance of sediment deposition and denitrification for nutrient retention in floodplain wetlands. Appl. Veg. Sci. 9 163-174.

OSBORNE LL and KOVACIC DA (1993) Riparian vegetated buffer strips in water quality restoration and stream management. Freshwater Biol. 29 243-258.
PAULSE AN, JACKSON VA and KHAN W (2007) Comparison of enumeration techniques for the investigation of bacterial pollution in the Berg River, Western Cape, South Africa. Water SA 33 165-173.

RAGUENEAU O, SCHULTES S, BIDLE K, CLAQUIN P and MORICEAU B (2006) Si and C interactions in the world ocean: importance of ecological processes and implications for the role of diatoms in the biological pump. Global Biogeochem. Cycles 20 (4) GB4S02.

ROUGET M, RICHARDSON DM, COWLING RM, LLOYD JW and LOMBARD AT (2003) Current patterns of habitat transformation and future threats to biodiversity in terrestrial ecosystems of the Cape Floristic Region, South Africa. Biol. Conserv. 112 63-85.

SHOTBOLT L (2010) Pore water sampling from lake and estuary sediments using Rhizon samplers. J. Paleolimnol. 44 695-700.

SIBSON R (1981) A brief description of natural neighbor interpolation. In: Barnett V (ed.) Interpolating Multivariate Data. John Wiley \& Sons, New York. 21-36.

SODERBERG K (2003) Geochemistry of the Fynbos Ecosystem in a Table Mountain Group Sub-Catchment of the Olifants River, Western Cape, South Africa. M.Sc. Thesis, University of Cape Town, Cape Town.

STANFORD JA, WARD JV, LISS WJ, FRISSELL CA, WILLIAMS RN, LICHATOWITZ JA and COUTANT CC (1996) A general protocol for restoration of regulated rivers. Regul. Rivers Res. Manage. 12 391-413.

STREET-PERROTT AF and BARKER PA (2008) Biogenic silica: a neglected component of the coupled global continental biogeochemical cycles of carbon and silicon. Earth Surf. Proc. Land. 33 1436-1457.

STRUYF E, VAN DAMME S, GRIBSHOLT B, MIDDELBURG JJ and MEIRE P (2005) Biogenic silica in tidal freshwater marsh sediments and vegetation (Schelde estuary, Belgium). Mar. Ecol. Prog. Ser. 303 51-60.

STRUYF E and CONLEY DJ (2009) Silica: an essential nutrient in wetland biogeochemistry. Front. Ecol. Environ. 7 88-94.

STRUYF E, OPDEKAMP W, BACKX H, JACOBS S, CONLEY DJ and MEIRE P (2009) Vegetation and proximity to the river control amorphous silica storage in a riparian wetland (Biebrza National Park, Poland). Biogeosciences 6 623-631

STRUYF E, MAGNUS-MÖRTH C-M, HUMBORG C and CONLEY DJ (2010) An enormous amorphous silica stock in boreal wetlands. J. Geophys. Res. 115 G04008

STRUYF E, KOTOWSKI W, JACOBS S, VAN DAMME S, BAL K, OPDEKAMP W, BACKX H, VAN PELT D and MEIRE P (2011) Tracing Si-N-P ecosystem-pathways: is relative uptake in riparian vegetation influenced by soil moisture, mowing management and species diversity? Hydrobiologia 674 41-50

SURRIDGE BWJ, HEATHWAITE AL and BAIRD AJ (2007) The release of phosphorus to porewater and surface water from river riparian sediments. J. Environ. Qual. 36 1534-1544.

TABACCHI E, CORRELL DL, HAUER R, PINAY G, PLANTYTABACCHI AM and WISSMAR RC (1998) Development, maintenance and role of riparian vegetation in the river landscape. Freshwater Biol. 40 497-516.

VAN DAMME S, DEHAIRS F, TACKX M, BEAUCHARD O, STRUYF E, GRIBSHOLT B, VAN CLEEMPUT O and MEIRE $P$ (2009) Tidal exchange between a freshwater tidal marsh and an impacted estuary; the Scheldt estuary, Belgium. Est. Coast. Shelf Sci. 85 197-207.

WALINGA I, VAN VARK W, HOUBA VJG and VAN DER LEE JJ (1989) Plant analysis procedures. Soil and Plant Analysis, Part 7. Agricultural University, Wageningen. 13-16.

WARD JV, TOCKNER K, UEHLINGER U and MALARD F (2001) Understanding natural patterns and processes in river corridors as the basis for effective river restoration. Regul. Rivers Res. Manage. 12 311-323.

WASSEN MJ, PEETERS WHM and VENTERINK HO (2003) Patterns in vegetation, hydrology, and nutrient availability in an undisturbed river floodplain in Poland. Plant Ecol. 165 27-43. 